\title{
Representasi Perempuan Indonesia Dalam Ajang Penghargaan Televisi (Studi Feminisme pada Penghargaan Indihome Women Award Di Metro TV)
}

\author{
Ahmad Toni \\ Fakultas Ilmu Komunikasi Universitas Budiluhur Jalan Salemba Ciledug Nomor 34-36Z \\ No. Telp. (021) 5686666 Fax (021) 5633719 Jakarta, \\ Email: tonianthonovubl@gmail.com
}

\begin{abstract}
Television personality award for the motor marketing television programs itself, the need to raise the rating and share. The awards were recently held by MetroTV devoted to female finalists Indonesia called modern Kartini. This study aimed to describe the representation of women in the awards Indihome Women Award at Metro TV. The method used consciousness-raising method, a method to generate knowledge and awareness in terms of women's issues and women movement within the frame of the mass media (television). This study used a qualitative descriptive method with emphasis on the reality of the media that have a relationship or context with social reality in Indonesia. The results showed the awards event Indihome Women Award in Metro women disepresentasikan as duality and ambiguity in the system of nation building; (1) Women look no further indicate the identity and values alignment on national development map but are represented at the level of the worse off, (2) Women made a movement which is represented as a capitalist agent, (3) Women and the movement into the implementation of a number of representations of themselves and movements performed in the frame of self falsehood.
\end{abstract}

Keyword: representation, women, capitalist comodity

\begin{abstract}
Abstrak
Penghargaan bagi insan pertelevisian menjadi motor pemasaran program stasiun televisi itu sendiri, kepentingan untuk menaikan rating dan share. Ajang penghargaan yang akhir-akhir ini diadakan oleh MetroTV dikhususkan untuk finalis perempuan Indonesia yang disebut dengan Kartini modern. Penelitian ini bertujuan untuk mendeskripsikan representasi perempuan dalam ajang penghargaan Indihome Women Award di MetroTV. Adapun metode yang digunakan consciousness-raising method, metode untuk menimbulkan pengetahuan dan kesadaran dalam hal isu-isu perempuan dan gerakan perempuan dalam bingkai media massa (televisi). Penelitian ini sifatnya deskriptif kualitatif dengan menekankan pada realitas media yang mempunyai hubungan atau konteks dengan realitas sosial di Indonesia. Hasil penelitian menunjukan dalam ajang penghargaan Indihome Women Award di MetroTV perempuan disepresentasikan sebagai dualitas dan ambiguitas dalam sistem pembangunan bangsa dan negara; (1) Perempuan terlihat bukan semakin menunjukan jati diri dan nilai kesejajaran pada peta pembangunan nasional tetapi direpresentasikan pada level yang semakin terpuruk, (2) Perempuan dijadikan suatu gerakan yang direpresentasikan sebagai agen kapitalis, (3) Perempuan dan gerakannya menjadi implementasi atas sejumlah representasi dirinya dan gerakan yang dilakukan dalam bingkai kepalsuan diri.
\end{abstract}

Kata kunci: representasi, perempuan, komoditas kapitalis 


\section{Pendahuluan}

Berbagai ajang penghargaan yang diselenggarakan oleh sejumlah televisi nasional Indonesia dewasa ini membuat penonton tidak yakin akan objektivitas penyelenggara. Ajang pengharagaan televisi hanya sebagai marketing program acara yang mereka miliki, bahwa pemasaran media televisi dalam ajang penghargaan adalah pesta atas sejumlah para pengiklan yang dominan dalam berbagai macam program acara yang mereka punyai.

Hubungan iklan dan program acara di televisi adalah hubungan materi keuntungan bagi pihak televisi dan sebagai bentuk penghargaan atas loyalitas sejumlah produk iklan yang setia memasang tayangan produk mereka di stasiun televisi tersebut. Pada substansinya ajang penghargaan yang terbesar yakni Panasonic Global Award pun sempat diboikot oleh beberapa stasiun televisi nasinal Karena diduga melakukan praktik illegal dengan pihak stasusn televisi penyelenggara yakni RCTI. SCTV, Trans TV dan Trans7 serta televisi lain memboikot objektivitas penilaian dan objektivitas penyelenggaraannya.

Penghargaan bagi insan pertelevisian menjadi motor pemasaran program stasiun televisi itu sendiri, kepentigan untuk menaikan rating dan share salah satunya ialah dengan mengadakan ajang penghargaan. Strategi ini sangat efektif mengingat sejumlah artis, aktor dan aktris, pengusaha, perwakilan iklan dan lain-lain dapat berkesempatan untuk hadir secara bersama-sama. Praktik ajang penghargaan ialah praktik kepentingan bisnis media dalam menyongsong persaingan antar stasiun televisi dalam rangka meraih simpati publik. Ajang penghargaan saat ini bukan sekedar memberikan penghargaan, penghormatan, apresiasi atas capaian, prestasi yang sudah diraih, tapi penghargaan untuk dapat mencapai sesuatu yang lebih besar lagi bagi kepentingan materi, keuntungan perusahaan.

Ajang penghargaan televisi akhir-akhir ini disiarkan oleh Metro TV sebagai media patner dalam momentum peringatan Hari Kartini. Ajang pengahargaan ini mencoba untuk menghadirkan sejumlah finalis dari berbagai bidang kehidupan dan dari berbagai wilayah di Indonesia. Penghargaan yang dikhususkan untuk finalis perempuan Indonesia yang disebut dengan Kartini modern. Kartini Indonesia dalam berbagai bidang kehidupan bangsa ini muncul sebagai panutan dan sekaligus menjadi tantangan bagi generasi muda Indonesia dalam memandang persaingan dalam globalisasi.Hadirnya nilai-nilai bangsa yang beriringan dengan segala dinamika kehidupan membuat sejumlah perempuan Indonesia melakukan hal-hal positif yang mampu memberikan inspirasi untuk segenap bangsa Indonesia. Perempuan Indonesia bukan hanya berkutat pada urusan keluarga, peran mereka dituntut lebih karena banyaknya aktivitas yang harus dilakukan sebagai komitmen perannya yang luar biasa pada keluarga, lingkungan dan sosialnya.

Berdasarkan uraian diatas, permasalahan yang ingin diangkat dalam tulisan ini adalah bagaimana representasi perempuan dalam ajang penghargaan Indihome Women Award di Metro TV. Tujuan penelitian ini adalah memaparkan citra atau representasi perempuan dalam ajang penghargaan Indihome Women Award di Metro TV.

Pada abad ke-18 dimana mula-mula proses industrialisasi bergerak cepat dan meninggalkan dampak yang paling besar pada perempuan borjuis terutama yang sudah menikah. Perempuan dalam kelompok ini ialah para perempuan yang merasakan tinggal di rumah dan tidak mempunyai pekerjaan poduktif dikarenakan mereka menikahi para kaum laki-laki profesional dan pengusaha yang berkecukupan. Wollstonecraft menyebut perempuan golongan ini sebagai perempuan-perempuan "beruntung" yang diharapkan dapat terinspirasi untuk mencapai cara bereksistensi yang lebih manusiawi (Tong, 2008:18). Perempuan kelas menengah yang selanjutnya disebut sebagai perempuan "peliharaan" jika dapat mengorbankan kesehatan, kebebasan dan moralitas untuk prestise, kenikmatan dan kekuasaan yang telah disediakan suaminya. Karena perempuan kelas menengah ini tidak diizinkan untuk berolahraga di luar rumah, dikawathirkan hal ini akan menggelapkan kulitnya yang putih seperti Bunga Lily, menjadi tubuh mereka tidak sehat.Dan karena mereka dihambat untuk mengembangkan kemampuan nalarnya dengan alas an hal yang terbaik yang dapat dilakukan adalah dengan memanjakan diri 
dan menyenangkan orang lain, terutama laki-laki (suami) dan anak-anak.

Konsep gender yakni suatu sifat yang melekat pada kaum laki-laki maupun perempuan yang dikonstruksi secara sosial maupun secara kultural (Fakih, 1996:8). Semisal, bahwa perempuan itu dikenal lemah lembut, cantik, emosional, atau keibuan. Sementara laki-laki dianggap kuat, rasional, jantan dan perkasa. Sejarah perbedaan gender antara jenis laki-laki dan perempuan terjadi melalui proses yang sangat panjang dan terbentuknya konsep gender dibentuk, diasosiasikan, diperkuat bahkan dikonstruksi secara sosial dan kultural. Konsep gender kemudian melahirkan marginalisasi yang kemudian mengakibatkan kemiskinan, di banyak studi yang dilakukan dalam rangka membahas program pembangunan pemerintah yang menjadi penyebab kemiskinan. Dari pola yang dibentuk oleh legilitas negara dan lakilaki tersebut ialah pandangan gender yang ternyata menimbulkan subordinasi terhadap perempuan. Pandangan semacam ini yang menempatkan kaum perempuan sebagai kaum yang irassional atau emosional sehingga perempuan tidak bisa memimpin yang kemudian berakibat munculnya sikap yang menempatkan perempuan pada posisi yang tidak penting. Subordinasi karena gender tersebut terjadi dalam segala macam bentuk yang berbeda dari tempat ke tempat dan dari waktu ke waktu. Selanjutnya terjadi pelabelan atau stereotype yang menimbulkan ketidakadilan terhadap perempuan yang ditandakan sebagai kaum pinggiran dan lemah tidak mampu menggunakan logika untuk memandang memandang dunia.

Karena diabaikan kesempatannya untuk mengembangkan diri dan kekuatan nalarnya, untuk menjadi manusia yang bermoral dan perhatian, motif dan komitmen yang jauh lebih besar dari sekedar kenikmatan pribadi, laki-laki juga seperti perempuan, akan menjadi sangat emosional. Para pemerhati feminimisme mengistilahkan hal tersebut sebagai hipersensitivitas narsisme yang ekstrim dan pemanjaan yang berlebihan.Feminsme membutuhkan suatu gerakan aksi sebagai perluasan wacana dalam masyarakat.
Ketidakadilan gender secara kongkret kita hadapi bersama dalam segala lini kehidupan. Keadaan hidup ini merupakan akibat dari ketimpangan gender yang berawal dari ketimpangan relasi antara perempuan dan laki-laki. Dalam sejarahnya kajian feminis yang banyak digunakan ialah dalam ruang konfigurasi sejarah dan budaya untuk penyadaran tentang kedudukan yang berbeda antara laki-laki dan perempuan. (Wiratmoko, 2006:45-46).

Sementara John Stuart Mill dan Harriet Taylor Mill dalam Rosemarie (2008:30) menyatakan bahwa perkembangan feminisme pada abad ke-19, perempuan harus memiliki hak pilih agar dapat setara dengan laki-laki. Di dalam posisi tidak saja untuk mengekspresikan pandangan politik personal seseorang, tetapi juga untuk mengganti sistem, struktur dan sikap yang dapat memberikan kontribusi terhadap operasioperasi terhadap orang lain, atau operasi terhadap dirinya. Agela Devis menunjukkan bahwa gerakan-gerakan hak-hak perempuan abad ke-19 pada dasarnya merupakan urusan perempuan terdidik, kelas menengah dan (kulit) putih. (Rosmerie, 2008:31). Perempuan dapat berpartisipasi secara setara dengan lakilaki dalam berbagai perdagangan, profesi dan juga bisnis dan bahkan politik. Sejauh perkembangnya dalam memperjuangkan hak-hak perempuan kajian utamanya hanya pada perempuan kulit putih. Pembicaraan persamaan hak perempuan kulit hitam hanya sebatas wacana dan masih mengkaji kontribusi perempuan kulit hitam untuk perjuangan kesetaraan peran dalam masyarakat.

Selanjutnya pada abad ke-20 untuk mendapaatkan kebebasannya perempuan membutuhkan kesempatan ekonomi dan juga kebebasan sipil. Semangat yang mereka miliki ialah semangat revolusioner kiri, yang tujuannya bukan untuk mereformasi apa yang dianggap mereka sebagai sistem elitis, kapitalis, kompetitif dan individual, melainkan untuk segera menggantikannya dengan system yang egaliter, sosialistik, koorporatif, komuniter dan berdasarkan pada gagasan sisterhood-is-powerful (persaudaraan perempuan adalah kuat), yang kemudian dikenal dengan feminis radikal. (Rosmerie, 2003:34). Friedan menegaskan dalam The Second Stage adalah perbedaan antara seorang feminis yang percaya bahwa perempuan dapat menjadi setara dengan laki-laki jika 
masyarakat menghargai yang "feminism" dan "maskulin" secara keseluruhan. Penegasan berikutnya ketika feminimine mystique ialah jika perempuan menjadi lakilaki, ia tidak akan terbebaskan. Artinya manusia yang utuh, secara ringkas, ialah berpikir dan bertindak layaknya seperti lakilaki.

Perkembangan selanjutnya penggembaran The Second Stage ialah sebagai penggambaran sebagai gaya pemikiran dan tindakan beta yang menekankan pada "fluiditas, fleksibelitas dan sensitivitas interpersonal" sebagai feminism secara budaya, dan menggambarkan gaya pemikiran dan tindakan alfa yang menekankan pada "hirarki, otoritas, kepemimpinan yang secara tegas berorientasi tugas berdasarkan rasionalistas instrumental dan teknologi sebagai feminis yang maskulin secara budaya". Freidan menyimpulkan bahwa "hukum yang spesifik terhadap gender adalah lebih baik daripada hukum yang netral gender dalam memastikan kesetaraan di antara dua jenis kelamin". (Rosmerie: 2008:45). Memperlakukan laki-laki dan perempuan secara setara berarti memperlakukan keduanya dengan cara yang sama. Jika laki-laki tidak seharusnya menerima perlakuan khusus karena jenis kelaminnya, maka perempuan pun tidak seharusnya menerima perlakuan khusus.

Feminisme radikal-kultural dan radikal liberal, Gayle Rubin memaknai sistem seks atau gender adalah suatu rangkaian pengaturan yang digunakan oleh masyarakat untuk mentransformasikan seksualitas biologis menjadi produk kegiatan manusia. Masyarakat patriarkal menggunakan fakta mengenai fisiologi perempuan dan laki-laki sebagai dasar untuk membangun serangkaian identitas dan perilaku untuk memberdayakan laki-laki dan melemahkan perempuan.

Konstruksi budaya telah jelas secara alamiah dan karena itu normalitas seseorang bergantung pada kemampuannya, untuk menunjukkan identitas gender secara kultural yang dihubungkan atas dasar jenis kelamin biologis seseorang. Aliran pertama mengklaim bahwa gender terpisah dari jenis kelamin, dan masyarakat patriarkal menggunakan peran gender yang kaku, untuk memastikan bahwa perempuan tetap pasif penuh kasih sayang, penurut, tanggap terhadap simpati dan persetujuan, ceria, baik dan ramah.
Di sisi lain laki-laki ditampilkan sebagai makhluk yang aktif, kuat, agresif, penuh rasa ingin tahu, ambisius, penuh rencana, bertanggung jawab dan kompetitif. Karena itu cara untuk menghancurkan kekuasaan lakilaki yang tidak layak terhadap perempuan ialah dengan pertama-tama menyadari bahwa perempuan tidak ditakdirkan untuk menjadi pasif dan kemudian mengembangkan kombinasi apa pun sifat feminisme dan sifat maskulin yang baik untuk dapat merefleksikan kepribadian unik yang dimilkinya masing-masing.

Kate Millet berpendapat bahwa "seks adalah politis". (Rosmerie, 2008:73). Sejauh pandangan mengenai seks ditujukan pada paradigma kekuasaan. Kasta sosial mendahului bentuk inegaliterianisme diantaranya ras, politik, ekonomi dan jika penerimaan terhadap laki-laki sebagai hak sejak lahir. Karena kendali laki-laki di dunia publik dan private terutama status, peran dan temperamen seksual. Munculnya feminisme sebagai bentuk apresiasi heterogenitas dunia maupun sebagai refleksi posisi subjek yang berbeda, tuntutan gender terus berusaha menghapus batas-batas kodrati yang harus dilewati. (Ben, 2005:215). Dalam konteks yang nyata dalam realitas keseharian perempuan menuntut adanya hak yang sama dengan lakilaki. Representasi kultural perempuan secara erat terkait dengan eksploitasi ekonomis dan politis pada perempuan itu sendiri. Semakin jauh dalam perkembangannya perempuan selalu menjadi objek dan sekaligus juga menjadi subjek yang prosentasenya kurang seimbang dengan dominasi kaum laki-laki dalam ranah kehidupan, baik kegiatan ekonomi, politik, struktural, lembaga dan di dalam rumah. Tujuan utamanya ialah perempuan memegang peranan penting dalam bingkai kehidupan. Peran tersebut berupaya memberikan nuansa untuk memunculkan suatu pandangan tentang perannya di dalam masyarakat.

Ideologi laki-laki yang menekankan peran maskulin yang dominan sedangkan perempuan mempunyai peran subordinat (menerima). Hal ini dikonstruksi dari institusi akademi, agama dan peran keluarga. Seksualitas bagi ideologi laki-laki ialah lokus kekuasaan laki-laki yang merupakan tempat gender dan hubungan gender dikonstruksikan.Ideologi laki-laki yang kemudian menciptakan pandangan terhadap perempuan tertuang dalam aktivitas seksual, 
mendorong laki-laki untuk memperlakukan perempuan sebagai warga negara kelas dua, bukan saja di dalam dunia pribadi di dalam kamar tidur, melainkan juga di dalam dunia publik di tempat kerja dan lingkungan, bersosial dan bernegara. Aliran kedua mengkritisnya dengan menyatakan bahwa feminis bukan hanya mengkaji perlakuan perempuan sebatas erotika dan thantika (publik). Hubungan seksual yang baik ialah lembut, menyentuh, bersisian (bukan satu di atas satu di bawah) yang kesemuannya menghasilkan hubungan seksual yang indah. Begitu pun peran dalam wilayah publik perempuan biasa memposisikan diri sebagai alur utama atau subjek bagi dirinya sendiri.

Pemikiran Marxis tentang feminis cenderung menunjukkan identifikasi klasisme dan bukan pada seksime. (Rosmerie, 2008:139). Marx percaya bahwa modus produksi suatu masyarakat yaitu dorongandorongan produksinya bahan baku, alat dan pekerja yang secara aktual menghasilkan produk, ditambah hubungan produksinya yang kemudian menghasilkan suprastruktural: lapisan gagasan hukum, politik dan sosial atau klasis. Feminimime sosialis yang diwakili tokonya Louis Althusser dan Jurgen Habermas menegaskan penyebab fundamental opresi terhadap perempuan bukan klasisme atau seksisme melainkan suatu keterikatan yang sangat rumit antara kapilaisme dan patriarkal. (Rosmerie, 2008:139). Adalah sesuatu yang dikhawatirkan oleh Jaggar bahwa feminis pada pendekatan pekerja yang tereksploitasi tidak menderita dengan cara yang sama, seperti isteri dan pelacur yang teropresikan oleh keadaan patriarkal.

Bagi aliran sosialis ketidaksetaraan kekayaan adalah penyeban pelacuran, sebagaimana hal yang sama terjadi pada kaum buruh. Selama masih ada kaum perempuan yang membutuhkan uang dan tanpa keahlian yang dapat dipasarkan, perempuaan-perempuan ini sangat mungkin akan memilih untuk menjual tubuhnya untuk menghidupi anak-anaknya. Karena itu, melawan kapitalisme adalah juga melawan pelacuran dalam bentuk apapun termasuk dalam bentuk "perkawinan". Feminisme sosialis kontemporer menekan bahwa cara kapitalisme berinteraksi dengan patriarki secara jauh lebih buruk dengan laki-laki. Pembebasan perempuan bergantung pada penghapusan kapitalisme, kapitalisme dapat dihancurkan jika patriarki juga dihancurkan dan bahwa hubungan material dan ekonomi manusia tidak dapat berubah kecuali jika ideologi mereka juga dirubah.Sentimen pertama kali muncul ketika pers pada sekitar tahun 1920-an mengadakan serangan katakata melalui media terhadap peran gender. Dengan cepat organisasi-organisasi feminis mulai terjungkal, dan kelompok perempuan yang tersisa dengan serta merta mencela amandemen persamaan hak atau dengan sederhananya mengubah diri menjadi klubklub sosial. Bagi Faludi dalam Ann Brooks (2006: 4) "agenda gerakan kaum feminis jelaslah diatur oleh media dan dirancang untuk meruntuhkan tujuan dan pencapaian kaum feminis. Media pada masa itu merancang dan mendeklarasikan bahwa feminisme adalah cita rasa dan posfeminisme adalah cerita baru". Peran media sangat berpengaruh terhadap membingkai pemahaman umum yang negatif dan popular mengenai segala aspek perempuan. Pada tahun 1980-an penerbit di Amerika dari New York Time, Vanity Fair hingga The Nation telah mengeluarkan dan mengkonstruksi tuduhan yang senantiasa melawan gerakan perempuan dengan kepala berita "Ketika Feminisme Gagal", "Kebenaran yang Mengerikan Tentang Pembebasan Perempuan". Mereka menganggap kampanye untuk persamaan hak perempuan bertanggung jawab pada semua kesengsaraan yang telah mengkungkung perempuan, dari depresi sampai kekurangan tabungan, dari bunuh diri remaja ke penyakit ketidakberaturan makan sampai corak kulit yang buruk (Brooks, 2006:5).

Selanjutnya dalam budaya kontemporer media massa dalam laporan-laporan feminisme ditulis kembali, dipolitisasi dengan bingkai feminisme tidak perlu antifeminis. Kontruksi perempuan terus berkembang seiring perkembangan kajian ilmu komunikasi terlebih lagi komunikasi yang sudah memakai visualisasi digital. Sebagai contoh konstruksi perempuan dalam bingkai konstruktivisme. Dalam paradigma komunikasi dimana konstruksivitas realitas sosial dilihat sebagai hasil konstruksi sosial, dimana kebenaran suatu realitas sosial bersifat relatif. (Hidayat, 1999:34).Penjelasan secara ontologis realitas sosial yang dikonstruksi berlaku sesuai dengan konteks yang dinilai relevan oleh pelaku sosial. Seperti yang dinyatakan oleh Burhan Bungin (2008:113) tidak sedikit orang mengangumi keindahan perempuan sebagai "karya seni" 
terindah di dunia. Kekuatan keindahan perempuan mengalahkan apapun di dunia ini,karena itulah dalam keindahan itulah tersimpan kehidupan yang menjadi pusat perhatian interaktif antara objek keindahan dan subjeknya. Keindahan perempuan menjadi stereotype perempuan dan memebawa mereka ke alam sifat keindahan, seperti perempuan harus selalu tampil menawan, cantik, wangi, pandai mengurus rumah tangga, memasak, tampil prima di setiap kesempatan, bersuara merdu, menyenangkan suami dan pantas diajak ke berbagai acara, cerdas serta sumber pengetahuan untuk keluarga.

Sifat dan kecenderungan iklan ialah kecenderungan yang mendekati logika pembohong (Bungin, 2008:115). Berbohong dalam dunia iklan tidak ada hubungannya dengan maksud merugikan pemirsa, namun semata-mata sebagai pelajaran semiotika. Di sisi lain iklan juga dikonstruk untuk menembus dimensi waktu dan tempat. Sebagai sebuah bahasa komunikasi untuk mengkonstruk masyarakat iklan mempunyai struktur bahasanya sendiri. Pembohongan dan penipuan yang sering dituduhkan pada iklan, bagaimana pun harus disampaikan lewat "bahasa" (Piliang, 2005:280). Kekuatan iklan untuk mengkonstruksi masyarakat didasari atas sistem teknologi yang mempengaruhi jalan pikiran masyarakat. Penciptaan realitas tersebut menggunakan satu model produksi yang disebut sebagai simulasi, yakni penciptaan model-model nyata yang tanpa asal-usul atau tanpa realitas awal. (Piliang, 2005:228). Kemudian penciptaan model melahirkan proses penciptaan citra terhadap perempuan. Pada kenyataanya iklan media cetak dan disusul iklan media siar diproduksi atau diciptakan untuk maksud pencitraan.

Pada umumnya pencitraan iklan televisi disesuaikan dengan kedekatan jenis objek iklan yang diiklankan, pencitraan itu antara lain: (1) Pencitraan perempuan, (2) Pencitraan maskulin, (3) Pencitraan kemewahan dan ekslusif, (4) Pencitraan kelas social, (5) Pencitraan kenikmatan, (6) Pencitraan manfaat, (7) Pencitraan persahabatan (8) Pencitraan seksisme dan seksualitas.

Sebuah iklan biasanya menawarkan sebuah citra yang dalam konteks bahasa iklan dapat dijelaskan sebagai gambaran mental dari sesuatu yang sebenarnya tidak ada. Citra digunakan untuk mengorganisir relasi konsumsi, serta relasi sosial yang terbentuk. Citra akhirnya menjadi instrumen utama dalam menguasi jiwa, membentuk dan mengubah tingkah laku setiap orang yang dipengaruhinya. Landasan citra kemudian menjadi unsur dasar dalam memilih sebuah produk. Media massa berikutnya yang berkaitan dengan feminisme ialah film. Mayne dalam Ann Brooks (2008:125) menyatakan bahwa perkembangan simultan dari sinema dan psikoanalisis, secara obsesif lewat sinema yang diteorikan oleh psikoanalisis bagi sinema sebagai suatu manifestasi penjelasan Frued mengenai aparat psikis. Bagi feminis, kegunaan potensial dari psikoanalisis ialah merefleksikan penanaman yang bergairah dalam mengambil dan menegaskan perempuan sebagai subjek di dunia representasi, kepenontonan, kesarjanaan dan produksi (Brook, 2008:126).

Salah satu kesulitan yang dihadapi feminis adalah kecenderungan psikoanalisis untuk mengambil wacana film ke dalam suatu orbit phalosentris dan menganggapnya berasal dari identitas sebagai permasalahan yang universal dan keterpaksaan yang kemudian menjadi suatu pandangan esensialis tentang kajian gender. Di dalam kajian film feminis bukanlah seperti keterikatan antara dimensi-dimensi kesejarahan dan ideologis, namun fakta kontemporer yakni hubungan imajiner dan simbolik yang menjadikan perbedaan seksual merupakan daya tarik penentu yang sentral.Hubungan yang telah diciptakan film feminis antara sinema klasik dan evaluasi terhadap suatu sinema perempuan alternatif merupakan corak dan nuansa feminis dalam film, yakni merepresentasikan dualisme yang ada antara sinema klasik dan sinema perempuan alternatif. Konsep dan teori film yang utama termasuk semiologi, teori psikoanalisis, realisme dan tatapan laki-laki (male gaze). Tujuan tersebut untuk mengembangkan kritik film feminis, khususnya masalah penyimpangan feminisme dan strukturalisme, psikoanalisis dan juga semiologi.

Kaplan menyatakan dalam Ann Brooks (2008:127) konsep psikoanalisis berguna untuk mencari konstruksi perempuan dalam sinema Holywood klasik. Di mana psikoanalisis dan semiologi memungkinkan perempuan untuk membuka kunci budaya 
patriarkal seperti ekspresi dalam representasi dominan yang dilakukan oleh laki-laki melalui kuasa sosial, politik, ekonomi dan seksual terhadap perempuan. Film merupakan sistem tanda yang berfungsi sebagian besar pada tingkat mitos. Tanda beroperasi melalui dua tingkat, yakni denotatif dan konotatif. Denotatif merefleksikan suatu penanda dan makna yang spesifik dan konotatif ialah sebuah refleksi atas proses memberikan makna dalam konteks kebudayaan atau ideologis tertentu. Dalam bahasanya Yasraf Piliang (2005:54) kedua tanda tersebut disebut sebagai "proper sign dan pseudo sign". Proper sign ialah tanda yang sebanarnya, tanda yang mempunyai hubungan relatif simetris dengan konsep atau realitas yang direpresentasikannya. Sedangkan pseudo sign disebut sebagai tanda palsu, suatu tanda yang bersifat tidak tulen, tiruan berpretensi, gadungan yang di dalamnya berlangsung semacam reduksi realitas.

\section{Metode Penelitian}

Penelitian ini lebih menekan pada consciousness-raising method, metode untuk menimbulkan pengetahuan dan kesadaran dalam hal isu-isu perempuan dan gerakan pemermpuan dalam bingkai media massa (televisi). Penelitian ini sifatnya deskriptif kualitatif dengan menekankan pada realitas media yang mempunyai hubungan atau konteks dengan realitas sosial di Indonesia. Hasil penelitian ini diharapkan dapat memberikan pemahaman tentang ketidaksadaran perempuan dalam menentukandiri dalam pembangunan bangsa.

\section{Hasil Penelitian dan Pembahasan Gambaran Umum Kartini Masa Kini}

Perempuan masa kini bukanlah perempuan yang hanya berurusan pada urusan dapur, sumur dan kasur. Di era modern serba digital ini, perempuan secara aktif dapat melakukan berbagai aktivitas, dengan tetap berkomitmen pada perannya sebagai ibu, istri, sahabat, saudara dan sesama perempuan. Kartini masa kini dapat menjelajah dunia dengan akses internet melalui laptop, tablet, $P C$, ponsel dan smartphone. Media jejaring sosial seperti facebook, twitter dan blog menjadi saluran mereka untuk berjuang, menjalin persahabatan, berbagi informasi, bertukar ide, menabur pengalaman inspriratif, hingga mengekspresikan segala kompetensi yang ada. Segala keterbatasan yang menyempitkan gerak perempuan pun bisa diretas dari rumah, perempuan menjelajah dunia, inilah perempan di era digital.

\section{Kriteria Umum Dalam Penghargaan Indihome Women}

Beberapa kriteria yang diukur dalam ajang penghargaan tersebut diantaranya: (a) Memiliki kontribusi positif terhadap lingkungannya, (b) Mampu menginspirasi banyak orang, (c) Kreatif dan inovatif, (d) Memiliki prestasi yang diakui msayarakat, (e) Konsisten di bidangnya, (f) Aktif menggunakan teknologi digital untuk memunjang bidang yang digelutinya (minimal 2 tahun terakhir di social media, blog, website), (g) Pelanggan indihome yang secara aktif menggunakan layanan Telkom, (h) Menjalankan peran sebagai ibu rumah tangga yang baik.

\section{Proses Penjurian Dalam Penghargaan Indihome Women}

Proses penyaringan pemenang penghargaan ini dialkukan secara ketat dan kredibel dengan mengusung 363 kandidat yang kemudian disaring dengan verification data menjadi 105 kandidat kemudian disaring oleh dewan juri menjadi 49 kandidat. Dengan mengedepankan tiga tahap penjurian, yakni juri yang ditunjuk, juri social media dan juri public vote. Berikut ini adalah pemenang di setiap kategori yang dipilih berdasarkan pada keputusan dewan juri, antara lain: 
Tabel 1. Pemenang dan Kategori Penghargaan

\begin{tabular}{|c|c|}
\hline Nama Pemenang & Kategori Penghargaan \\
\hline Herawati Sudoyo & $\begin{array}{l}\text { Indihome Women Cultural Artis: Peletak Dasar } \\
\text { Pemeriksaan DNA Forensik }\end{array}$ \\
\hline Keri Lestari Dandan & $\begin{array}{l}\text { Indihome women cultural artis: Pembuat obat } \\
\text { antidiabetes dari buah pala }\end{array}$ \\
\hline Aleta Baun & $\begin{array}{l}\text { Indihome women environmentalis: Penyelamat hutan } \\
\text { sacral }\end{array}$ \\
\hline Rukmini Paata Toheke & $\begin{array}{l}\text { Indihome women environmentalis: Pelestrai alam dan } \\
\text { adat }\end{array}$ \\
\hline Mita Julinartati Sirait & $\begin{array}{l}\text { Indihome women environmentalis: Penggiat lingkungan } \\
\text { dan daur ulang sampah }\end{array}$ \\
\hline Farha Ciciek & $\begin{array}{l}\text { Indihome women educator: Penggagas tanoker } \\
\text { community }\end{array}$ \\
\hline Kisw anty & Indihome women educator: Pustakaw an Keliling \\
\hline Nursyida Syam & $\begin{array}{l}\text { Indihome women educator: Pendiri sekolah alam anak } \\
\text { negeri dan klub membaca perempuan }\end{array}$ \\
\hline Jully Tjendrawan & Indihome women preneur: CEO world robotic explorer \\
\hline Safrida Harahap & $\begin{array}{l}\text { Indihome women preneur: Pemilik online shop cahaya } \\
\text { lampu }\end{array}$ \\
\hline Tri Kristianingsih & Indihome women preneur: Penggerak ekonomi produktif \\
\hline Aisyah Dahlan & $\begin{array}{l}\text { Indihome women healt activist: Pelita bagi mantan } \\
\text { pecandu narkoba }\end{array}$ \\
\hline Mia Susanto & Indihome women healt activist: Pelopor Asi Indonesia \\
\hline Dessy Suprihartini & $\begin{array}{l}\text { Indihome women healt activist: Relawan kesehatan } \\
\text { parungpanjang }\end{array}$ \\
\hline Esthi Susanti Hudiono & $\begin{array}{l}\text { Indihome women human care activist: aktivis HIV, anak } \\
\text { dan perempuan }\end{array}$ \\
\hline Lian Gogali & $\begin{array}{l}\text { Indihome women human care activist: pejuang } \\
\text { perdamaian }\end{array}$ \\
\hline Ari Sunarijati & $\begin{array}{l}\text { Indihome women human care activist: Pejuang buruh } \\
\text { perempuan }\end{array}$ \\
\hline Herawati Sudoyo & $\begin{array}{l}\text { Indihome women Scientist and Technology: Peletak dasar } \\
\text { DNA forensic }\end{array}$ \\
\hline Is Helianti & $\begin{array}{l}\text { Indihome women Scientist and Technology: peneliti } \\
\text { rekayasa genetika enzim }\end{array}$ \\
\hline Keri Lestari Dandan & $\begin{array}{l}\text { Indihome women Scientist and Technology: Pembuat obat } \\
\text { antidiabetes dari buah Pala }\end{array}$ \\
\hline Najw a Sihab & Indihome Inspiring women: Jurnalis \\
\hline Christine Hakim & Indihome Inspiring women: A ktris \\
\hline Melly Goeslaw & Indihome Inspiring women: Penyanyi \\
\hline
\end{tabular}

Representasi Perempuan Dalam Penghargaan Indihome Women

Representasi Pengguna Produk 'Telkom" Dalam penghargaan ini ada nuansa ketidakmurnian dalam penilaian, bahwa penghargaan adalah bentuk pemberian tanda atas jasa-jasa yang telah dilakukan u oleh seseorang dan memberikan hal-hal positif kepada masyarakat sekitarnya tanpa dipandang apakah pelaku ataaktor perubahan tersebut pengguna produk Telkom atau bukan. Sebagai konsekuensi atas jasa yang telah diberikan tanpa pamrih, atas konsekuensi moralitas yang tanpa berbalas dari pihak mana pun 
Kehadiran produk dalam penghargaan ini sebagai syarat penilaian atau kriteria yang menjadikan bahwa kekuasaan hadir menjadi bentuk representasi relasi kekuasaan produk sebagai agen kapitalis untuk menghegemoni kekuatan jasa-jasa para perempuan dalam menjalankan fungsi sosial masyarakatnya. Gerakan perempuan dalam pemberdayaan masyarakat atas segala daya dan kekuatannya menjadi termarginalkan, menjadi sub-ordinal dari kekuatan hegemoni kapitalis yang membutuhkan citra bagi kekuasaan modal yang dimilikinya.

Dalam pandangan kaum kapitalis media, gerakan perempuan dan para feminis dipandang sebagai agen kelas kedua dalam bisnis mereka, bahwa kelas pertama dalam pandangan kaum kapitalis ialah perempuan yang menjadi kekuatan bagi industri bisnis yang mereka jalankan. Binis kapitalis yang dibungkus citra kekuasaan dan hegemoni ideologi mereka dengan menggandeng setiap hal-hal relasi sistem sosial itu adalah perempuan sebagai agen perubahan bisnis mereka, bahwa perempuan diadalah nilai jual dalam diri keluarga, tetangga, rekan dan sistem sosial yang melingkupinya. Perempuan direpresentasikan sebagai iklan berjalan yang mewajibkan aktivitas mereka dibungkusi ideologi produk. Ideologi produk yang telah memberi penghargaan bagi dirinya, maka penghargaan itu menjadi bagian commercial bagi produk pemberi penghargaan. Adapun konstruks yang terbangun dari penghargaan ini meliputi halhal sebagai berikut: (a) Perempuan citra, (b) Bintang iklan, (c) Intelektual komersil, (d) Pengakuan palsu, (e) Kesadaran pujian.

Pada hakikatnya penghargaan ini lahir sebagai kebutuhan akan pigur-pigur pembawa citra yang dapat secara langsung bersentuhan dengan berbagai aspek kehidupan, baik secara ekonomi, sosial, politik dan budaya. Perempuan diorientasikan sebagai citra riil dalam kehidupan, citra yang dilahirkan oleh produk dan bertujuan untuk mengemban makna citra produk sebagai sebuah kegiatan rutinitas dirinya yang selalu membawa pesan informasi dari produk yang menghargai dirinya sebagai perempuan terpuji. Tugas yang diemban perempuan yang mendapatkan penghargaan dari daan bertema produk tertentu ialah perempuan selalu membawa corporate image sebagai nilai-nilai dirinya dan apa yang dihasilkannya. Secara jelas posisi perempuan dalam tataran penghargaan ialah ia merupakan relasi ideologi kapitalis yang berusaha menyusup pada realita sosialnya. Ia sebenarnya menjali alat relasi ideologi atas kepentingan mempersuasi lingkungan dan sosialnya. Ia sama dengan alat ideologi (hegemoni) lain yang berusaha untuk merubah kestabilan realitas menjadi bentuk kestabilan realitas yang diinginkan oleh kaum kapitalis. Keadaan ini menaruh harapan bagi kaum kapitalis dalam merubah sistem sosial, ekonomi, pendidikan dan budaya kaum perempuan Indonesia menjadi sistem sosial, ekonomi, pendidikan dan budaya yang direkayasa oleh kaum kapitalis tersebut.

Hal demikian bila tidak disadari oleh kaum perempuan, maka sistem sosial perempuan, realitas ekonomi perempuan, realitas pendidikan perempuan, realitas budaya perempuan menjadi realitas kapitalisme. Ruang gerak perempuan dalam hal ini dicoba untuk digerakan oleh kaum kapitalis sebagai ruang gerak yang menghasilkan materi, ruang yang memberikan keuntungan besar, ruang yang dapat memberikan hasil bagi pundi-pundi kaum kapitalis, mengingat perempuan yang sangat penting dalam sistem masyarakat Indoensia, perempuan sebagai penggerak segala lini kehidupan bangsa ini.

\section{Representasi Perempuan Indonesia}

Kartini era digital ialah bentuk konotasi yang sekaligus repesentasi perempuan pada era teknologi, bahwa kartini melakukan sebuah gerakan perempuan disegala bidang dan lini kehidupan. Gerakan atau feminisme yang lahir dari perempuan yang idealis dan membumi dan tentunya bisa dirasakan hal positifnya bagi masyarakat sekitarnya. Gerakan perempuan untuk dan dengan pemberdayaan kaumnya menjadi bukti bahwa perempuan Indonesia ialah bentuk perempuan yang menjadi masyarakat kelas utama dalam sistem pembangunan nasional dalam mengentaskan berbagai persoalan bangsa. Perempuan bukan sebagai subordinal dari kaum laki-laki dalam proses pembangunan bangsa dan negara. Perempuan Indonesia direpresentasikan sebagai daya kekuatan untuk mengelola asetaset penting bangsa dan negara, peran 
perempuan dalam berbagai lapisan sistem sosial tidak kalah penting dari peran laki-laki. Bahwa semangat materialisme yang dibawa oleh perempuan menggambarkan bahwa ide dan gagasan mereka lebih bersifat realistis dalam kehidupan dan realitas nyata.

Representasi perempuan Indonesia merupakan dualism antara kekuatan produk dengan semangat yang dimilikinya yang lahir dari hati nurani, moral, cipta, karsa dan di implementasikan dalam kehidupan nyata bagi dirinya dan lingkungannya. Representasi perempuan sebagai kekuatan utama bangsa ini memberikan kesetaraan dalam peran dan fungsi antara kaum laki-laki dengan kaum perempuan dalam sistem pembangunan bangsa.

Pada hakikatnya perempuan direpresentasikan sebagai kaum yang kuat, berpendidikan dan merupakan pondasi sistem nilai dalam masyarakat Indonesia. Perempuan Indonesia diposisikan pada peranan strategis dalam membangun bangsa, juga diposisikan sebagai penggerak kesadaran intelektual, sehingga perempuan Indonesia beradas pada wilayah general yang setara dengan kaum yang lain. Namun konstruksi demikian hadir dan dihadirkan oleh kepentingan kapitalis (pemodal) dalam rangka kampanye produk, maka terdapat perbedaan yang sangat tipis pada hal ini antaralain:

(A)Perempuan terpuji (pengharagaan) sebagai pengerak pemodal dalam menjalankan bisnisnya. Perempuanperempuan yang mendapatkan penghargaan tersebut ialah citra berjalan perusahaan yang membutuhkan kampanye produk secara riil dalam sistem masyarakat sebagai wujud kampanye komersil. Pada dataran ini perempuan dipandang pada level manfaat semata. Bahwa perempuan ialah alat yang sangat riil untuk mengkamapnyekan produk di dalam sistem masyarakat dengan agenda perusahaan yang berorientasi binis semata. Perempuan yang mendapatkan penghargaan ialah sama dengan bintang iklan di televisi yang berusaha untuk mempersuasi lingkungananya dengan segala kekuatan dirinya. (B) Perempuan terpuji (penghargaan) sebagai simbol budaya komersil yang diidentifikasikan pada nilai jual dirinya dalam sistem kaum patriarki. Dalam hal ini perempuan ialah lambang atas segala macam bentuk realitas, dengan hal ini maka perempuan ialah lambang dari kemakmuran bagi kaum patriarki. Perempuan dipandang sebagai objek kemakmuran dan kesuburan bagi dominasi patriarki. Sistem ini menunjukan semakin jelas objek-objek eksploitasi (C) erempuan dalam bidang domestik. Relasi antara penghargaan dengan sistem komersialisasi perempuan sendiri ialah simbol matinya eksistensi perempuan dalam wilayah-wilayah domenstik dan wilayah general. Perempuan ditarik kearah general namun ia kemudian ditempatkan sebagai objek domestik dari suatu produk komersil sebagai perwujudan diri perempuan yang teropresikan oleh produk yang memberikannya ruang kebahagiaan semu. (D) Perempuan terpuji (pengharaan) ialah representasi atas kapitalisasi perempuan dalam mewujudkan tujuan, visi dan misi sebuah perusahaan yang dilatarbelakangi oleh sejumlah persoalan perempuan yang tersegmentasi atas dasar perwujudan perempuan semata. Fregmentasi penghargaan pada perempuan justeru menambah jurang perbedaan gender antara perempuan dan laki-laki. Perempuan dalam hal ini teroptasikan pada sistem-sistem keperempuanan yang mereka buat sendiri. Penghargaan yang berbasis perempuan ini menandakan bahwa perempuan membuat sekat perbedaan dengan alam kesadarannya dalam rangka memperjuangkan hak-hak mereka untuk setara dengan kaum laki-laki. Perjuangan yang memungkinkan perempuan terpuruk pada sistem yang mereka perjuangkan sendiri. (E) Perempuan terpuji (penghargaan) ialah sebuah gerakan untuk mensejajarkan, mendidik, memerdekaan hak-hak perempuan sebagai kaum yang turut berpartisipasi dalam kehidupan berbangsa dan bernegara. Artinya kesadaran kaum perempuan pada sistem-sistem dan alat perjuangan sebagai indikator perempuan sebagai kaum yang dinamis dalam perkembangan zaman. Usaha ini menempatkan perempuan sebagai motor penggerak sistem sosial, pendidikan, ekonomi dan juga budaya.( F) Perempuan terpuji (penghargaan) capaian perjuangan perempuan dalam mensejejarkan diri dengan elemen pembangunan secara holistik, eksistensi perempuan sebagai bentuk penghargaan setinggi-tingginya bagi kehidupan ini.

Terjadi dualisme dan ambiguitas dalam representasi perempuan pada penghargaan Indihome Women. Perempuan dalam sisi idealisme mengusung nilai-nilai positif yang lahir dari semangat, ide, pemikiran, gagasan dan perspektif perempuan sebagai kekuatan utama dalam proses pembangunan bangsa. Gerakan atau semangat feminisme yang dilahirkan 
dari konsepsi perempuan menjadi titik tolak dan tolak ukur dari kehadiran semangat murni dari dasar nilai-nilai humanisme yang dimiliki oleh perempuan. Perempuan menjadi nilai semangat, nilai inspirasi, nilai moralitas bagi generasi muda bangsa di era teknologi digital. Namun dilain sisi representasi perempuan sebagai agen produk dalam menginspirasi orang lain, dikarenakan hadirnya nilai produk 'telkom' menjadi bentuk representasi perempuan sebagai agen commercial dalam sistem masyarakat. Kedua representasi tersebut akan melahirkan hal-hal berikut ini: (1) Perempuan dalam gerakan membangun sistem sosial tidak lebih sebagai pelengkap agen kapitalis, (2) Perempuan dalam gerakan sosial menjadi kepanjangan nilai ekonomi korporasi, (3) Gerakan perempuan sebagai nilai jual perusahaan, (4) Gerakan perempuan sebagai komoditas of idea.

Dari kelima elemen yang timbul diatas perempuan justeru diposisikan dalam posisi yang lemah dan termarjinalkan, sebuah bukti pelecehan atas gerakan perumpuan itu sendiri. Bahwa perempuan semakin dipandang sebagai kaum yang teropresikan dalam sistem modern dunia digital. Perempuan semakin dipandang sebagai kaum pelengkap sebuah produk. Gerakan perempuan pun adalah pelengkap atas produk itu sendiri sebagai bentuk kekerasan terhadap perempuan dalam otoritas binsis. Perempuan dan gerakanya menjadi manifestasi atas sejumlah citra yang dibentuk dalam hegemoni kapitalis, mereka para perempuan dijadikan sebagai kanibalisme binis dan komoditas citra dari ide-ide kaum kapitalis yang secara sengaja membentuk citra dengan menjadikan perempuan kaum yang semakin lemah yang dikonstruksi oleh agenagen kapitalisme sebagai otoritas kesadaran palsu yang dibangun oleh produk.

Kodrat perempuan yang menjadi ibu rumah tangga menjadi kebutuhan dasar atas alasan kaum kapitalis yang dengan kesengajaan melahirkan stigma perempuan pada level arus sosial yang menjadi takdirnya, perempuan tidak boleh meninggalkan kodrat dan takdirnya sebagai ibu rumah tangga, bahwa dalam budaya patriarki perempuan menjadi bagian dan perannya sangat sentral dalam mengurus rumah tangga. Dosa terbesar perempuan ketika rumah tangga yang dibinanya menjadi runtuh, dan banyak perempuan dipersalahkan atas kejadian retaknya rumah tangga. Proses penilain dan indikator yang harus dimiliki oleh perempuan ini adalah mencerminkan perempuan sebagai nahkoda rumah tangga dan bertanggung jawab atas keutuhan rumah tangga. Laki-laki menjadi penilai atas nahkoda yang dijalankan oleh perempuan dan sangat memberikan ruang untuk menghakimi apa yang dilakukan oleh perempuan dalam menjalankan biduk rumah tangganya.

\section{Simpulan}

Dalam pandangan hegemoni kaum kapitalis dalam merepresentasikan perempuan sebagai dualitas dan ambiguitas dalam sistem pembangunan bangsa dan negara, bahwa perempuan direpresentasikan sebagai berikut:

1. Perempuan bukan semakin menunjukan jati diri dan nilai kesejajaran pada peta pebangunan nasional tetapi direpresentasikan pada level yang semakin terpuruk.

2. Perempuan sebagai suatu gerakan direpresentasikan sebagai agen kapitalis.

3. Perempuan dan gerakannya menjadi implementasi atas sejumlah representasi dirinya dan gerakan yang dilakukan dalam bingkai kepalsuan diri.

Pada substansinya perempuan dijadikan alat ideologi atau disebut dengaan hegemoni bagi kaum kapitalis dalam rangka membuat realitas perempuan menjadi realitas yang direkayasa oleh kaum kapitalis. Realitas perempuan yang dapat menghasilkan pundipundi kekayaan kaum kapitalis, mengingat peran perempuan dalam sistem sosial, ekonomi, pendidikan dan budaya sangat sentral. Penempatan perempuan sebagai citra perusahaan (produk) tersebut ialah hal yang tepat untuk mengeruk keuntungan dari lingkungan perempuan, kaum kapitalis memposisikan perempuan sebagai kekayaan yang megandung ketidaksadaran diri.

\section{Daftar Pustaka}

Ann, Brooks. (2008). Posfeminisme dan Cultural Studies. Yogyakarta: Jalasutera.

Burhan, Bungin. (2008). Konstruksi Sosial Media Massa. Jakarta: Kencana Prenada Media Group.

Deny, Hidayat. (1999). Paradigma dan Perkembangan Penelitian Komunikasi. Jakarta: IKSI dan Rosda. 
Wiratmoko, Dheny dkk. (2006). Feminis Muda Membuat Perubahan. Yogyakarta: Kinasih

Mansour, Fakih. (1996). Analisis Gender dan Transformasi Sosial. Yogyakarta: Pustaka Pelajar

Rosemarie, Putnam Tong. (2008). Feminist Thought. Yogyakarta: Jalasutera.

Yasraf, Amir Piliang. (2005). Hipersemiotika, Tafsir Cultural studies Atas Matinya Makna. Yogyakarta: Jalasutera.

(2005). Dunia yang Dilipat

Tamasya Melampaui Batas-Batas Kebudayaan. Yogyakarta: Jalasutera.

Internet

http:/ / www.indihomewomenaward.com/ 